\title{
Expression of receptors for verotoxin 1 from Escherichia coli 0157 on bovine intestinal epithelium
}

\author{
D. E. ELAINE HOEY, CAROL CURRIE, RODERICK W. ELSE*, ANITA NUTIKKA†, \\ CLIFFORD A. LINGWOOD†, DAVID L. GALLY and DAVID G. E. SMITH
}

Zoonotic and Animal Pathogens Research Laboratory, Department of Medical Microbiology, University of Edinburgh, *Department of Veterinary Pathology, Easter Bush Veterinary Centre, University of Edinburgh, Edinburgh, UK and †Department of Infection, Immunity, Injury and Repair, Hospital for Sick Children, Toronto, Canada

\begin{abstract}
Human enterohaemorrhagic Escherichia coli (EHEC) infection most commonly arises, either directly or indirectly, from cattle, which act as a reservoir host for these bacteria. In man, EHEC disease can be severe, whereas EHEC do not normally cause disease in cattle. Verotoxins (VTs) are the main virulence factors in human disease but no role for VT has been ascribed in cattle; however, this study shows for the first time that VT receptor is expressed by the bovine intestinal tract. VT bound to crypt epithelial cells of the small (ileum and jejunum) and large (caecum and colon) intestine independently of the animals' age. VT also bound to discrete cell subsets in the bovine kidney and to submucosal lymphoid cells but not to vasculature. Analysis of tissues for isoforms of the VT receptor, Gb3, confirmed the presence of the receptor in the bovine intestinal epithelium and kidney. A distinct pattern of Gb3 receptor isoform mixtures was observed in the bovine kidney. This, together with the general absence of receptors on vasculature, could contribute to the apparent resistance of cattle to systemic effects of VT. Expression of Gb3 on the bovine intestinal epithelium, together with previously described effects, may affect EHEC colonisation in its reservoir hosts and hence the potential for distribution to man.
\end{abstract}

\section{Introduction}

Enterohaemorrhagic Escherichia coli (EHEC) are a subclass of verotoxigenic E. coli (VTEC) [1], among which those belonging to serogroup $\mathrm{O} 157$ have been successful in the widespread colonisation of cattle $[2,3]$. E. coli $\mathrm{O} 157$ has emerged as a significant cause of severe food-borne disease in man [4] with outbreaks occurring regularly [5-8]. Although E. coli O157 can cause severe diseases in man (e.g., haemorrhagic colitis and haemolytic uraemic syndrome), infection in cattle is normally asymptomatic $[2,3,9]$. It is possible that the lack of disease in cattle may have aided its spread; however, the basis for the success of EHEC in colonising cattle and their asymptomatic carriage remains undefined.

Received 2 May 2001; revised version accepted 28 Aug. 2001.

Corresponding author: Dr D. G. E. Smith (e-mail: dgesmith @ vet.ed.ac.uk).
Multiple factors are involved in EHEC virulence in man. These include Esp proteins (encoded by locus of enterocyte effacement; LEE) [10], intimin and Tir (also encoded by LEE) [11], plasmid-encoded determinants [12] and verotoxins (VTs), which are considered to be responsible for the severe damage in EHEC infection in man. VTs represent a family of bacterial compound toxins, the prototype of which is present in Shigella dysenteriae type 1 [13]. The holotoxin (c. $70 \mathrm{kDa}$ ) comprises a single $32-\mathrm{kDa}$ A subunit and five B subunits arranged as a pentamer [14]. In VTEC there are two main classes of verotoxins (VT1 and VT2) which are encoded on lysogenic bacteriophages that can be carried by strains in various combinations [15]. Targeting of VT and susceptibility is dictated primarily by expression of the globotriaosyl-ceramide (Gb3) family of glycolipids [16] which have been shown to be necessary in mediating cytotoxicity $[17,18]$. VT binds specifically to the galabiose terminal disaccharide moiety of globotriaosyl ceramide-Gb3 (Gal $\alpha 1-4-G a l \beta 1-$ 4 glucosyl ceramide) [19,20], also known as CD77 [21]. Gb3 may be distributed in different cell and tissue 
types in different hosts, thus defining the pathology of VT-induced diseases. Expression of Gb3 in the cell membrane generally reflects sensitivity to the cytotoxic activities of VTs ultimately leading to cell death, for which the following mechanisms have been proposed. The A subunit of VTs catalytically inactivate the $28 \mathrm{~S}$ RNA of $60 \mathrm{~S}$ ribosomal subunits leading to an inhibition of cellular protein synthesis [22, 23]. Furthermore, the holotoxin and the B subunit pentamer are capable of inducing programmed cell death (apoptosis) through a pathway independent of the suppression of protein synthesis [24]. VTs can induce necrosis [25], apoptosis [26, 27] or both in several cell types depending on the circumstances. Therefore, current evidence indicates that VT is a potent cytolethal toxin.

E. coli $\mathrm{O} 157$ has become widely distributed in cattle populations and factors that increase the success of EHEC in colonising cattle consequently increase the threat to human health. The successful colonisation by EHEC of cattle and their apparent resistance to disease caused by EHEC are the subject of much speculation. VT genes are retained in at least $95 \%$ of cattle isolates $[3,28,29]$, hence VT may confer some selective advantage in this host. VT is produced in the intestine of cattle $[30,31]$ and, although it does not appear to cause overt damage (as it does in man), may possess other important function(s).

The distribution of VT receptor along with other receptor characteristics is important in determining whether VT may be of significance in the interaction between EHEC and cattle. The present study examined tissues from cattle of two different age groups for VT receptor with a larger sample size than the study reported previously [32]. Bovine tissues were examined in detail for Gb3 by immunohistochemical and biochemical approaches. VT receptors have a novel distribution in cattle, an important finding that is in contrast to the conclusions of the previous study [32]. This suggests that VT may have a role in colonisation of cattle and these possible roles are discussed.

\section{Materials and methods}

\section{Preparation of verotoxin}

VT1 was prepared as described previously [20]. After removal of endotoxin by passage through a polymyxin B column, the concentration of VT1 was adjusted to $0.165 \mathrm{mg} / \mathrm{ml}$ in PBS and stored in small volumes at $-70^{\circ} \mathrm{C}$.

\section{Animals and tissue sampling}

Tissues were obtained from 1- and 10-month-old cattle ( $n=3$ for both age groups) submitted for routine postmortem examination (UK) or presented at abattoir (Canada). Necropsy commenced immediately following euthanasia and within 15 min of death duplicate tissue samples (rumen, jejunum, ileum, caecum, colon and kidney) were frozen in liquid nitrogen (for glycolipid extraction) or mounted in OCT (Merck) and frozen in a slurry of dry ice in isopentane (for immunohistochemical detection of VT receptor). Histopathological assessment of haematoxylin and eosin (H\&E)-stained sections indicated no pathological alterations in intestinal or renal samples; thus these samples were further processed for Gb3 analysis or immunohistochemical analysis of VT1 binding.

\section{Immunoperoxidase detection of VT1 binding to bovine tissue}

Sections $(6 \mu \mathrm{m})$ of frozen autopsy material derived from 1- and 10-month-old cattle $(n=3$ for both age groups) were cut with a Leica RM2155 microtome, mounted on to Biobond-coated slides (British Biocell International) and frozen at $-70^{\circ} \mathrm{C}$ until used. Air-dried frozen sections [33] of rumen, jejunum, ileum, caecum, colon and kidney were blocked sequentially with Peroxidase Block (DAKO), avidin, biotin (15 min each) and finally normal goat serum (NGS) $1 \%$ in phosphatebuffered saline (PBS) for $20 \mathrm{~min}$, with extensive washings with PBS between each step. Sections were overlaid with VT1 (50 or $200 \mathrm{ng} / \mathrm{ml}$ ), mouse anti-VT1 ( 1 in 250) and biotinylated anti-mouse $\operatorname{IgG}(1$ in 500) (Jackson Laboratories) for $30 \mathrm{~min}$ each. VT binding was detected with a Vectastain Elite Universal ABC elite kit (Vector Laboratories) and visualised with 3,3'diaminobenzidine tetrachloride (DAB; Vector Laboratories); the sections were counter-stained with haematoxylin. Sections were observed with a Leica DMLB epifluorescence microscope under incident illumination.

\section{Glycolipid extraction from bovine tissues}

Tissues of both 1- and 10-month-old cattle were homogenised $(1 \mathrm{~g} / \mathrm{ml})$ in PBS and the glycolipids were extracted with 20 volumes of chloroform:methanol (C:M, 2:1 v:v) overnight. A Folch partition against water was performed with each of the extracts [34]. The lower phase was dried and saponified with $1 \mathrm{M}$ $\mathrm{NaOH}$ in methanol for $2 \mathrm{~h}$ at $37^{\circ} \mathrm{C}$ to remove phospholipids from the mixture. The dried lower phase was dissolved in C:M 98:2 v:v and separated by silica chromatography according to the method described by Boyd and Lingwood [35]. The Gb3 present was detected by thin-layer chromatography (TLC) overlay binding with VT1.

\section{Assay of Gb3 content by VT1 TLC overlay}

Samples $(20-50 \mu \mathrm{g} / \mathrm{ml})$ of the glycolipid extracts of bovine tissue were separated by TLC (C:M:water 65:25:4 v:v:v) in parallel with appropriate standards $(0.5 \mu \mathrm{g} / \mu \mathrm{l})$, i.e., glucosylceramide (GlcCer; Sigma); lactosylceramide (LacCer); Gb3 and Gb4. The plates were dried and blocked with gelatin ( $1 \%$ in water) at 
$37^{\circ} \mathrm{C}$ overnight. They were then washed three times with $50 \mathrm{mM}$ Tris-buffered saline (TBS), $\mathrm{pH} 7.4$, for $5 \mathrm{~min}$ and incubated with VT1 $100 \mathrm{ng} / \mathrm{ml}$ for $1 \mathrm{~h}$ at room temperature. After further washing with TBS, the plates were incubated with mouse anti-VT1 antibody $(2 \mu \mathrm{g} / \mathrm{ml})$ [36] followed by horseradish peroxidaseconjugated goat anti-mouse IgG (1 in 2000) (DAKO) for $1 \mathrm{~h}$ at room temperature. Finally, after washing the plates with TBS, 4-chloro-1-naphthol peroxidase substrate was added to localise toxin binding. A similar plate was prepared and sprayed with orcinol to determine total glycolipid content.

\section{Results}

\section{Localisation of VT1 binding in bovine tissues}

Frozen tissue sections from the rumen, jejunum, ileum, caecum, colon and kidney from 1- and 10-month old cattle (three of each age) were incubated with purified VT1, either $50 \mathrm{ng} / \mathrm{ml}$ or $200 \mathrm{ng} / \mathrm{ml}$. Immunohistological examination of the jejunum, ileum, caecum and colon from both age groups identified VT1 bound to a subpopulation of epithelial cells (Figs. 1 and 2 show representative examples). Specifically, toxin binding localised to the crypts adjacent to the submucosa, a binding pattern that was observed with both concentrations of VT1. Non-specific binding of secondary antibody (with or without binding of primary antibody) to the sections as assessed by incubation without VT1, was not observed in any of the tissues examined (negative control, data not shown).

During histological examination of intestinal tissues from animals of both age groups, binding to subepithelial cells was also observed. VT1 attached to cells present in lymphoid aggregates within the lamina

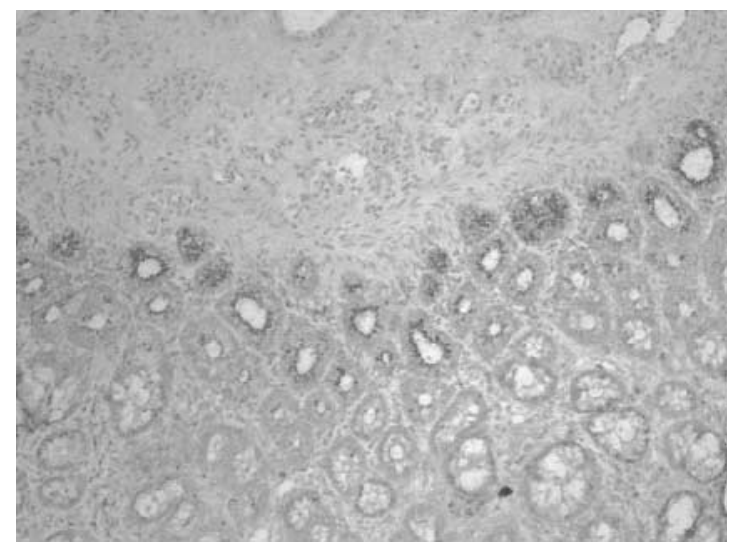

Fig. 1. Immunohistochemical localisation of VT1 binding to bovine intestinal epithelium. VT1 binding localised to crypt cells adjacent to the submucosa in tissue samples from jejunum, ileum, caecum and colon. This section of caecum from a 10-month-old cow was overlaid with VT1 $200 \mathrm{ng} / \mathrm{ml}$ and is representative of results obtained with intestinal tissues of cattle aged both 1 month $(n=3)$ and 10 months $(n=3)$. A similar binding pattern was observed with the lower concentration of VT1.

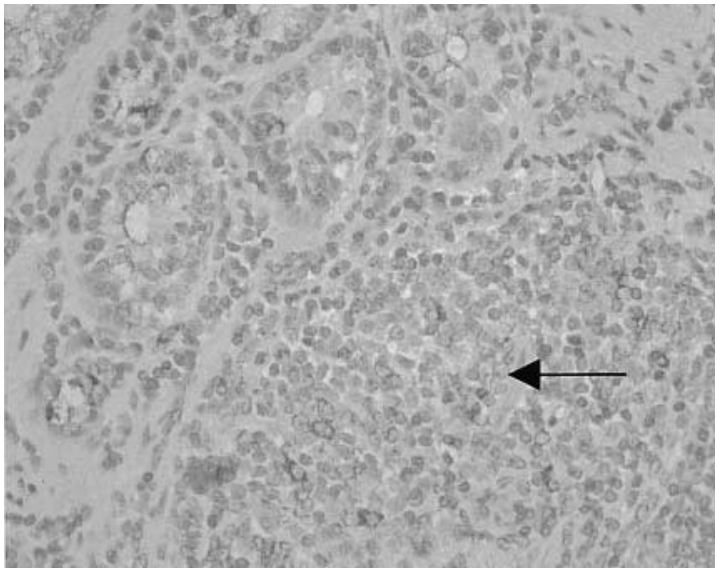

Fig. 2. Immunohistochemical localisation of VT1 binding to bovine lymphoid tissue in intestinal submucosa. This section of ileum was overlaid with VT1 $200 \mathrm{ng} / \mathrm{ml}$ derived from a 1month-old calf and is representative of results obtained with ileum from cattle aged both 1 month $(n=3)$ and 10 months $(\mathrm{n}=3)$. Parallel sections of ileum treated with VT1 $50 \mathrm{ng} / \mathrm{ml}$ showed identical receptor distribution (not shown). Similar results were obtained with sections of the colon and caecum $(n=3)$. Lymphoid aggregations in the subepithelium were stained with VT1 (arrow).

propria, a feature that was particularly evident in the ileum from both age groups (Fig. 2).

The results with kidney sections from 1- and 10-monthold cattle, obtained with a well-established method for detection of the Gb3 receptor [33], show a similar binding pattern to that recently reported with acetonefixed sections [32]. Although Gb3 could be solubilised from tissue by acetone treatment, as kidney retained receptor in the previous study [32], this treatment is presumably insufficient to remove all the glycolipids from this tissue (in contrast to intestine). Predominant staining was apparent in the convoluted tubules and collecting ducts within the renal cortex, with a complete absence of binding to the renal glomeruli and blood vessels (Fig. 3). VT1 binding to vasculature was not observed in the bovine jejeuum, ileum, caecum, colon and kidney ( $\mathrm{n}=3$ for both age groups).

\section{Expression of VT1 receptor}

Bovine intestinal samples were further examined for VT receptors by extraction and isolation of glycolipids from mucosa. Glycolipids $(20-50 \mu \mathrm{g} / \mathrm{ml})$ from each tissue extract were analysed by a thin-layer chromatography (TLC) VT overlay assay. Two bands (which are mixtures of isoforms) of Gb3 to which VT bound were identified in enteric (jejunum, ileum, caecum and colon) mucosa. Fig. 4a shows results from caecum and colon which are representative of all intestinal sites. VT bound to glycolipid bands from bovine intestinal mucosa which migrated at the same positions as those in the control Gb3 sample (human adult kidney). The extraction of the Gb3 receptor from these sites correlated with the VT1 binding observed in these tissues by immunohistochemistry. 


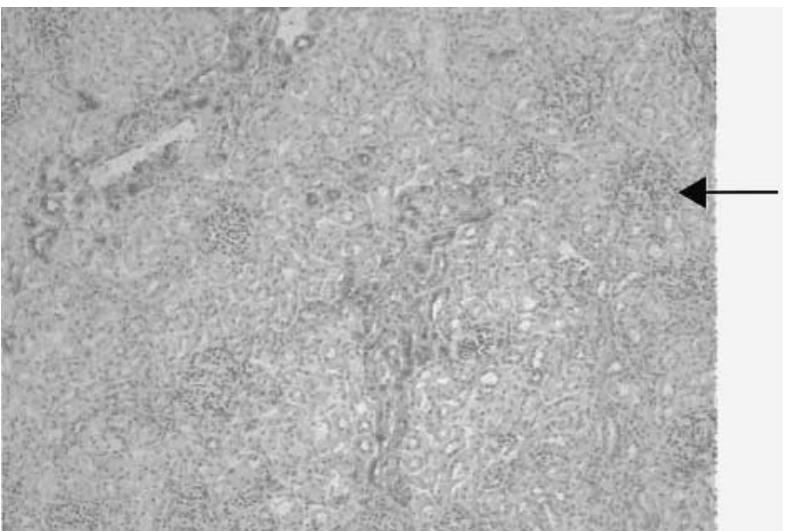

Fig. 3. Immunohistochemical localisation of VT1 binding to bovine kidney. This section overlaid with VT1 $200 \mathrm{ng} / \mathrm{ml}$ was derived from a 1-month-old calf and is representative of results obtained with kidney from cattle aged both 1 month $(\mathrm{n}=3)$ and 10 months $(n=3)$. A similar binding pattern was observed with the lower concentration of VT1. Binding of VT1 was detected mainly in the renal cortex, with predominant staining apparent in the convoluted tubules and collecting ducts. The absence of binding of VT1 to glomeruli (arrow) and blood vessels is evident.

Kidney from these animals was also examined for the expression of $\mathrm{Gb3}$ receptor. A triplet of bands was observed indicating three isoform mixtures of $\mathrm{Gb} 3$ receptor (Fig. 4b). One band of Gb3 in the kidney of both age groups of cattle was absent in the corresponding human tissue. In contrast to man, there were no tissue- and age-related differences in toxin binding in

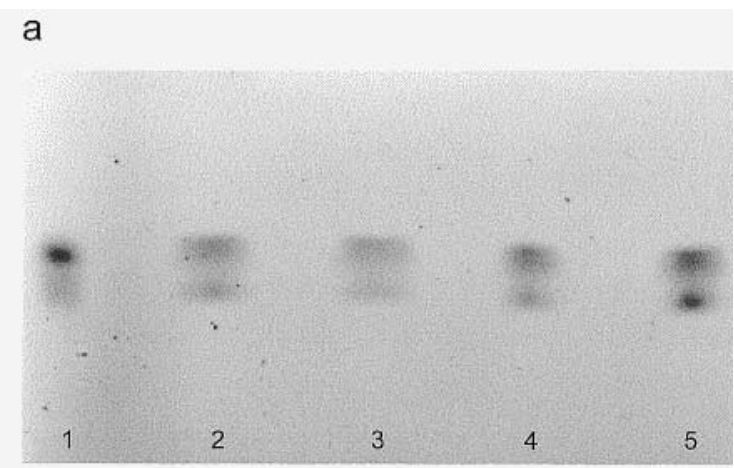

b

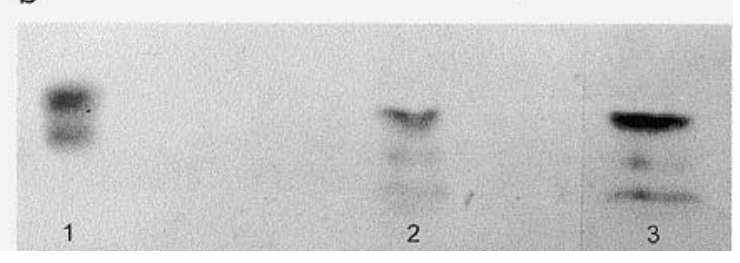

Fig. 4. VT receptor isolation from intestinal mucosa and bovine kidney. Glycolipids from 1- and 10-month-old cattle (three animals of each age) were analysed by TLC and the VT receptors were identified by toxin-binding overlay assay. (a) Lane 1, human adult kidney $(2 \mu \mathrm{g} / \mathrm{ml}) ; \mathbf{2}, \mathbf{3}$, colon of 1 - and 10 -month old cattle $(20-50 \mu \mathrm{g} / \mathrm{ml}) ; 4,5$, caecum from 1 - and 10-month-old cattle $(20-50 \mu \mathrm{g} / \mathrm{ml})$. (b) Lane 1, human adult kidney $(2 \mu \mathrm{g} / \mathrm{ml}) ; 2$, kidney from 1-month-old cow $(20$ $50 \mu \mathrm{g} / \mathrm{ml}) ; 3$, kidney from 10-month-old cow (20-50 $\mu \mathrm{g} / \mathrm{ml})$. cattle. VT1-binding glycolipids were extracted and quantified in three independent experiments and the above findings are representative of the results obtained.

\section{Discussion}

Cattle are the main reservoir of E. coli $\mathrm{O} 157$ and other EHEC $[37,38]$. In this host, infection is asymptomatic, although in man infection is serious and potentially fatal. Among the many virulence factors of EHEC, verotoxins (VTs) are the main factors responsible for the severe features of disease in man. Cattle are frequently colonised by VT-positive $E$. coli and as VTs can be detected in cattle faeces $[30,31]$ these animals are presumably less sensitive to VT toxicity. It has been suggested recently that this refractory nature of cattle may correspond to absence of VT receptor (Gb3) in most cattle tissues [32]; however, findings presented here contradict this suggestion and demonstrate that cattle do express VT receptor in a novel tissue and cellular distribution.

Immunohistochemical analysis of VT binding to tissue sections demonstrated localisation to epithelial cells in the crypt regions adjacent to the submucosa of jejunum, ileum, caecum and colon from both 1- and 10 -month old cattle. The presence of receptor in these sites was confirmed by lipid extraction and TLC overlay assay. These findings contrast with a previously published report that bovine intestinal epithelium lacks Gb3 [32]. However, the two studies differ in details of experimental procedures: the age of animals selected for investigation, tissue quantities and glycolipid isolation protocols and the preparation of tissue for immunohistochemistry. Notably, the present study used animals aged 1 and 10 months from both Scotland and Canada, whereas the study of Pruimboom-Brees et al. [32] used only a single colostrum-deprived neonatal $(<24 \mathrm{~h})$ calf to isolate VT receptors, and this animal may not be representative. Also, in the present study, snap-frozen tissue was used in a well-established procedure for assessing VT binding to tissue [33], whereas in the other study [32], tissue was acetonefixed. This process, in addition to permeabilising cells, may solubilise Gb3 and could account for the apparent absence of receptor suggested by that study. In the present study, this receptor distribution was reproducible on triplicate samples from six animals of different geographic origins. It must be concluded that VT receptor is present on bovine intestinal epithelium, localising specifically to a subpopulation of crypt cells.

Crypts are composed of mixed populations of cells including immature proliferating cells and differentiated cell types [39]. A subset of proliferating cells migrate towards the luminal surface and differentiate [39], acquiring the enzymic and morphological characteristics of the mature apical epithelium. Results 
showed that apical cells do not bind VT1, which presumably corresponds with loss of this receptor as these cells migrate and differentiate. Correlation between cellular proliferation/differentiation and VT binding has been demonstrated previously [40-42]. The binding of VT to bovine intestinal epithelium contrasts with the absence of receptor in human intestinal epithelium $[43,44]$ and, because of the noted activities of VT, this may be of significance during colonisation of cattle.

In addition to localisation at intestinal epithelium, VT1 also bound to submucosal lymphoid aggregates. There is growing evidence that VTs may target the immune system of the host. For instance, cattle lymphocytes showed a lower lymphocyte proliferation response after infection of calves with VTEC strains [45] and, more recently, Ferens and Hovde [46] reported a variety of immunomodulatory activities of VT1 through suppression of mononuclear cell activation and lymphocyte proliferation. Similar activities of VT are seen against lymphocytes from other sources, e.g., man [21,47]. Therefore, VT may modulate immune responses and hence affect pathogen-host interaction. To act as a modulator of immune responses VT would need to gain access to submucosal sites. The presence of VT receptors on a subpopulation of epithelial cells may prevent toxin translocation and it remains to be determined whether VT crosses the bovine intestinal epithelium and gains access to submucosal tissues.

VT bound to bovine kidney in a pattern that resembled that described in human adult kidney [33], i.e., tubules and collecting ducts. This distribution corresponds to reduced susceptibility to HUS as a consequence of toxicity of systemic VT. Receptor localisation was similar to that observed in a previous study [32], in which acetone fixation was applied. This procedure may solubilise Gb3 and other glycolipids; however, as kidney retained receptor in that study, this treatment is presumably insufficient to remove all glycolipids from this tissue. Intestine, in contrast to kidney, does not apparently retain $\mathrm{Gb} 3$ after acetone treatment. The differences resulting from this treatment may be due to a variety of structural and compositional differences between intestinal mucosa and kidney, which may account for the tissue-specific variation. Important among these may be receptor isoform(s); e.g., bovine kidney expressed a third form of Gb3 (Fig. 4), which was not detected in mucosal samples.

In man, in addition to targeting kidney, VTs also affect intestinal vascular cells as human endothelial cells express Gb3 [48,49] leading to haemorrhagic colitis [50]. VT1 binding to capillaries was not observed in the bovine jejunum, ileum, caecum, colon or kidney, in corroboration of previously published observations [32]. This was not unexpected as FACS and immunofluorescence microscopy (unpublished results) with CPAE cells, a bovine pulmonary artery endothelial cell line, indicated that these cells lack Gb3. The general scarcity of VT binding to blood vessels and kidney glomeruli may limit systemic effects of VT and further contribute to the absence of overt pathogenicity of $E$. coli $\mathrm{O} 157$ in cattle.

Binding of toxin correlates with the expression of the various forms of $\mathrm{Gb3}$, the VT receptor. To assess receptor forms in bovine tissues, glycosphingolipid species were isolated and analysed by a TLC VT overlay assay. Two VT-binding Gb3 bands were identified in enteric samples and three in kidney, with neither tissue showing age-related alterations. Thus, specific receptors in bovine intestine are responsible for the binding of VT1 to cells in tissue sections.

Intestinal epithelium in animals which do express epithelial Gb3 varies in susceptibility to VT toxicity [51-54]. VTs possess functions in addition to cytotoxicity, which could influence bacterium-host interaction. Firstly, by targeting crypt cells VTs may affect epithelial development. Infection of ruminants with $E$. coli $\mathrm{O} 157: \mathrm{H} 7$ has been shown by others [55] to reduce epithelial shedding which correlated with prolonged colonisation; the noted role of VT in suppressing cellular metabolism could contribute to this reduced cell turnover. Also, it has been demonstrated that VTs can elicit cytokines as a consequence of interaction with intestinal epithelial cells $[56,57]$ as well as directly affecting immune function. Thus, VTs may act as immunomodulators by influencing expression of mediators of inflammation, innate and adaptive immune responses.

There are several possible roles for VTs, which may affect both cellular physiology and host defences and thus influence colonisation and other outcomes of infection. All VTEC, and not just EHEC, contain VTencoding bacteriophage(s). Strains belonging to these types possess a range of other factors associated with virulence [1] and heterogeneity among these, particularly serotype-dependent variation, could account for the differences in pathogenicity for cattle shown by various EHEC and VTEC serotypes. The effects of VT on bovine epithelial cells are of great significance to the success of colonisation, dissemination and persistence of these organisms in cattle reservoirs.

This study and others indicate possible roles for VT; however, the precise function(s) of VT in cattle remain to be fully defined and will require further evaluation of effects of VT on bovine intestinal mucosa. Nevertheless, it can be concluded that the different consequences of E. coli O157 infection in man and cattle involve a multiplicity of host and bacterial factors. Among those, the disparity between cattle and man in the distribution of VT receptor on intestinal epithelium is a fundamental difference which could contribute to the differing consequences of $E$. coli O157 infection in these two hosts. 
This research was funded by a grant to D.L.G. and D.G.E.S. from the Department for Environment, Food and Rural Affairs (DEFRA) of the UK. The authors thank Dr A. Roe and Professor T. Besser for discussion and critical reading of the manuscript.

\section{References}

1. Nataro JP, Kaper JB. Diarrheagenic Escherichia coli. Clin Microbiol Rev 1998; 11: 142-201.

2. Chapman PA, Siddons CA, Wright DJ, Norman P, Fox J, Crick E. Cattle as a possible source of verocytotoxin-producing Escherichia coli $\mathrm{O} 157$ infections in man. Epidemiol Infect 1993; 111: 439-447.

3. Synge B, Paiba C. Verocytotoxin-producing E coli O157. Vet Rec 2000; 147: 27.

4. Qadri SMH, Kayali S. Enterohemorrhagic Escherichia coli - a dangerous food-borne pathogen. Postgrad Med 1998; 103: $179-187$.

5. Griffin PM. Epidemiology of Shiga toxin-producing Escherichia coli infections in humans in the United States. In: Kaper JB, O'Brien AD (eds) Escherichia coli O157:H7 and other Shiga-toxin producing E. coli strains. Washington, DC, American Society for Microbiology. 1998: 15-22.

6. Smith HR, Rowe B, Adak GT, Reilly WJ. Shiga toxin (verocytotoxin)-producing Escherichia coli in the United Kingdom. In: Kaper JB, O'Brien AD (eds) Escherichia coli O157:H7 and other Shiga-toxin producing E. coli strains. Washington DC, American Society for Microbiology. 1998: 49-58.

7. Spika JS, Khakhria R, Michel P, Milley D, Wilson J, Waters J. Shiga toxin-producing Escherichia coli infections in Canada. In: Kaper JB, O’Brien AD (eds) Escherichia coli O157:H7 and other Shiga-toxin producing E. coli strains. Washington, DC, American Society for Microbiology. 1998: 23-29.

8. Karmali MA, Petric M, Steele BT, Lim C. Sporadic cases of haemolytic-uraemic syndrome associated with faecal cytotoxin and cytotoxin-producing Escherichia coli in stools. Lancet 1983; 1: 619-620.

9. Elder RO, Keen JE, Siragusa GR, Barkocy-Gallagher GA, Koohmaraie M, Laegreid WW. Correlation of enterohemorrhagic Escherichia coli O157 prevalence in feces, hides, and carcasses of beef cattle during processing. Proc Natl Acad Sci USA 2000; 97: 2999-3003.

10. Knutton S, Rosenshine I, Pallen MJ et al. A novel EspAassociated surface organelle of enteropathogenic Escherichia coli involved in protein translocation into epithelial cells. EMBO J 1998; 17: 2166-2176.

11. Hartland EL, Batchelor M, Delahay RM et al. Binding of intimin from enteropathogenic Escherichia coli to Tir and to host cells. Mol Microbiol 1999; 32: 151-158.

12. Karch H, Schubert S, Zhang D et al. A genomic island, termed high-pathogenicity island, is present in certain non-O157 shiga toxin-producing Escherichia coli clonal lineages. Infect Immun 1999; 67: 5994-6001.

13. Acheson DWK, Donohue-Rolfe A, Keusch GT. The family of shiga and shiga-like toxins. In: Alonf JE, Free JH (eds) Sourcebook of bacterial protein toxins. London, Academic Press. 1991: 415-433.

14. O'Brien AD, Holmes RK. Shiga and shiga-like toxins. Microbiol Rev 1987; 51: 206-220.

15. Boerlin P, McEwen SA, Boerlin-Petzold F, Wilson JB, Johnson RP, Gyles CL. Associations between virulence factors of Shiga toxin-producing Escherichia coli and disease in humans. J Clin Microbiol 1999; 37: 497-503.

16. Lingwood CA. Verotoxins and their glycolipid receptors. $A d v$ Lipid Res 1993; 25: 189-211.

17. Boyd B, Tyrrell G, Malonney M, Gyles C, Brunton J, Lingwood C. Alteration of the glycolipid binding-specificity of the pig edema toxin from globotetraosyl to globotriasoyl ceramide alters in vivo tissue targetting and results in a verotoxin-1 like disease in pigs. J Exp Med 1993; 177: 1745-1753.

18. Waddell T, Cohen A, Lingwood CA. Induction of verotoxin sensitivity in receptor-deficient cell-lines using the receptor glycolipid globotriosylceramide. Proc Natl Acad Sci USA 1990; 87: 7898-7901.

19. Jacewicz M, Clausen H, Nudelman E, Donohue-Rolfe A, Keusch GT. Pathogenesis of shigella diarrhea.1. Isolation of a shigella toxin-binding glycolipid from rabbit jejunum and HeLa-cells and its identification as globotriaosylceramide. $J$ Exp Med 1986; 163: 1391-1404.

20. Lingwood CA, Law H, Richardson S et al. Glycolipid binding of purified and recombinant Escherichia coli produced Verotoxin in vitro. $J$ Biol Chem 1987; 262: 8834-8839.

21. Mangeney M, Lingwood CA, Taga S, Caillou B, Tursz T, Wiels J. Apoptosis induced in Burkitts-lymphoma cells via Gb3/CD77, a glycolipid antigen. Cancer Res 1993; 53: 5314-5319.

22. Endo Y, Tsurugi K, Yutsudo T, Takeda Y, Ogasawara T, Igarashi K. Site of action of a Vero toxin (VT2) from Escherichia coli O157:H7 and of Shiga toxin on eukaryotic ribosomes. RNA N-glycosidase activity of the toxins. Eur $J$ Biochem 1988; 171: 45-50.

23. Saxena SK, O’Brien AD, Ackerman EJ. Shiga toxin, Shiga-like toxin II variant, and ricin are all single-site RNA Nglycosidases of $28 \mathrm{~S}$ RNA when microinjected into Xenopus oocytes. J Biol Chem 1989; 264: 596-601.

24. Van Setten PA, Van Hinsbergh VWM, Van denHeuvel LPWJ et al. Verocytotoxin inhibits mitogenesis and protein synthesis in purified human glomerular mesangial cells without affecting cell viability: evidence for two distinct mechanisms. J Am Soc Nephrol 1997; 8: 1877-1888.

25. Matise I, Sirinarumitr T, Bosworth BT, Moon HW. Vascular ultrastructure and DNA fragmentation in swine infected with Shiga toxin-producing Escherichia coli. Vet Pathol 2000; 37: 318-327.

26. Arab S, Murakami M, Dirks $\mathrm{P}$ et al. Verotoxins inhibit the growth of and induce apoptosis in human astrocytoma cells. J Neuro-oncology 1998; 40: 137-150.

27. Taga S, Carlier K, Mishal Z et al. Intracellular signaling events in CD77-mediated apoptosis of Burkitt's lymphoma cells. Blood 1997; 90: 2757-2767.

28. Hancock DD, Besser TE, Rice DH, Herriott DE, Tarr PI. A longitudinal study of Escherichia coli O157 in fourteen cattle herds. Epidemiol Infect 1997; 118: 193-195.

29. Rice DH, McMenamin KM, Pritchett LC, Hancock DD, Besser TE. Genetic subtyping of Escherichia coli $\mathrm{O} 157$ isolates from 41 Pacific Northwest USA cattle farms. Epidemiol Infect 1999; 122: 479-484.

30. Ball HJ, Finlay D, Burns L, Mackie DP. Application of monoclonal antibody-based sandwich ELISAs to detect verotoxins in cattle faeces. Res Vet Sci 1994; 57: 225-232.

31. Van Donkersgoed J, Graham T, Gannon V. The prevalence of verotoxins, Escherichia coli O157: H7, and Salmonella in the feces and rumen of cattle at processing. Can Vet J 1999; 40: $332-338$.

32. Pruimboom-Brees IM, Morgan TW, Ackermann MR et al. Cattle lack vascular receptors for Escherichia coli O157: H7 Shiga toxins. Proc Natl Acad Sci USA 2000; 97: 10325-10329.

33. Lingwood CA. Verotoxin-binding in human renal sections. Nephron 1994; 66: 21-28.

34. Folch J, Lees M, Sloane-Stanley GH. A simple method for the isolation and purification of total lipids from animal tissues. J Biol Chem 1957; 226: 497-509.

35. Boyd B, Lingwood C. Verotoxin receptor glycolipid in human renal tissue. Nephron 1989; 51: 207-210.

36. Boulanger J, Petric M, Lingwood C, Law H, Roscoe M, Karmali M. Neutralization receptor-based immunoassay for detection of neutralizing antibodies to Escherichia coli verocytotoxin-1. J Clin Microbiol 1990; 28: 2830-2833.

37. Chart H. Are all infections with Escherichia coli $\mathrm{O} 157$ associated with cattle? Lancet 1998; 352: 1005.

38. Mead PS, Griffin PM. Escherichia coli O157: H7. Lancet 1998; 352: 1207-1212.

39. Fenoglio-Preiser C M, Lantz P, Listrom M, Noffsinger A, Rilke F Stemmermann G. Gastrointestinal pathology: an atlas and text, 2nd edn. New York, Lippincott-Raven. 1998.

40. Jacewicz MS, Acheson DWK, Mobassaleh M, Donohue-Rolfe A, Balasubramanian KA, Keusch GT. Maturational regulation of globotriaosylceramide, the shiga-like toxin 1 receptor, in cultured human gut epithelial cells. J Clin Invest 1995; 96: $1328-1335$.

41. Obrig TG, Delvecchio PJ, Karmali MA, Petric M, Moran TP, Judge TK. Pathogenesis of haemolytic uraemic syndrome. Lancet 1987; 2: 687.

42. Pudymaitis A, Lingwood CA. Susceptibility to verotoxin as a function of the cell cycle. J Cell Physiol 1992; 150: 632-639. 
43. Holgersson J, Jovall PA, Breimer ME. Glycosphingolipids of human large intestine: detailed structural characterization with special reference to blood group compounds and bacterial receptor structures. J Biochem 1991; 110: 120-131.

44. Kasai K, Galton J, Terasaki PI et al. Tissue distribution of the $\mathrm{Pk}$ antigen as determined by a monoclonal antibody. J Immunogenet 1985; 12: 213-220.

45. Menge C, Wieler LH, Schlapp T, Baljer G. Shiga toxin 1 from Escherichia coli blocks activation and proliferation of bovine lymphocyte subpopulations in vitro. Infect Immun 1999; 67: 2209-2217.

46. Ferens WA, Hovde CJ. Antiviral activity of Shiga toxin 1: suppression of bovine leukemia virus-related spontaneous lymphocyte proliferation. Infect Immun 2000; 68: 4462-4469.

47. Hoffman KM, Ho DG, Sampson HA. Evaluation of the usefulness of lymphocyte proliferation assays in the diagnosis of allergy to cow's milk. J Allergy Clin Immunol 1997; 99: $360-366$.

48. Jacewicz MS, Acheson DWK, Binion DG et al. Responses of human intestinal microvascular endothelial cells to Shiga toxins 1 and 2 and pathogenesis of hemorrhagic colitis. Infect Immun 1999; 67: 1439-1444.

49. Ohmi K, Kiyokawa N, Takeda T, Fujimoto J. Human microvascular endothelial cells are strongly sensitive to Shiga toxins. Biochem Biophys Res Commun 1998; 251: 137-141.

50. Paton JC, Paton AW. Pathogenesis and diagnosis of Shiga toxin-producing Escherichia coli infections. Clin Microbiol Rev
1998; 11: 450-479.

51. Dykstra SA, Moxley RA, Janke BH, Nelson EA, Francis DH. Clinical signs and lesions in gnotobiotic pigs inoculated with Shiga-like toxin I from Escherichia coli. Vet Pathol 1993; 30: 410-417.

52. Keusch GT, Jacewicz M, Mobassaleh M, Donohue-Rolfe A Shiga toxin: intestinal-cell receptors and pathophysiology of enterotoxic effects. Rev Infect Dis 1991; 13 Suppl 4: S304-S310.

53. Richardson SE, Rotman TA, Jay $\mathrm{V}$ et al. Experimental verocytotoxaemia in rabbits. Infect Immun 1992; 60: 4154-4167.

54. Taylor FB, Tesh VL, DeBault L et al. Characterization of the baboon responses to Shiga-like toxin. Descriptive study of a new primate model of toxic responses to Stx-1. Am J Pathol 1999; 154: 1285-1299.

55. Magnuson BA, Davis M, Hubele S et al. Ruminant gastrointestinal cell proliferation and clearance of Escherichia coli O157: H7. Infect Immun 2000; 68: 3808-3814.

56. Yamasaki C, Natori Y, Zeng XT et al. Induction of cytokines in a human colon epithelial cell line by Shiga toxin 1 (Stx1) and Stx 2 but not by non-toxic mutant Stx1 which lacks Nglycosidase activity. FEBS Lett 1999; 442: 231-234.

57. Thorpe CM, Hurley BP, Lincicome LL, Jacewicz MS, Keusch GT, Acheson DWK. Shiga toxins stimulate secretion of interleukin-8 from intestinal epithelial cells. Infect Immun 1999; 67: 5985-5993. 